\title{
The Relentless Hazard: \\ Allied Maritime Strategy and Climate Change
}

\author{
Alix Valenti
}

Any examination of the relationship between NATO and climate change could very easily be misconstrued as the beginning of a joke. Something along the lines of: "What do climate change and NATO have in common? They are both full of hot air!" The troubled relationship between Trump and NATO during his four years as $45^{\text {th }}$ President of the US ${ }^{1}$, as well as French President Emmanuel Macron's assertion, in November 2019, ${ }^{2}$ that NATO is becoming brain-dead, ${ }^{3}$ have indeed done little to publicly restore the reputation of the 71-year-old alliance. So, trying to understand the potential role of the alliance in something as seemingly unrelated as climate change could appear incongruous.

Yet sceptics would do well to dig a little deeper into the issue of climate change. If we move past the debate about whether it is man-made or notwhich is irrelevant to the following discussion-, very few doubts exist today as to its impact on international security. In fact, perhaps even more tellingly, in February 2020 the International Military Council on Climate and Security 4 (IMCCS) published the inaugural 'World Climate and Security Report 2020'. The foreword of the report notes that

1 In September 2020, there were still rumours that Trump might seek to leave the alliance if re-elected:

Michael Crowley, 'Allies and Former US Officials Fear Trump Could Seek NATO Exit in a Second Term', The New York Times, 3 September, 2020. https://www.nyti mes.com/2020/09/03/us/politics/trump-nato-withdraw.html.

2 The Economist, 'Emmanuel Macron warns Europe: NATO is becoming braindead', The Economist, 7 November, 2019.

https://www.economist.com/europe/2019/11/07/emmanuel-macron-warns-europenato-is-becoming-brain-dead.

3 An assertion he has since attempted to justify:

Patrick Wintour and Bethan McKernan, 'Macron defends 'brain-dead NATO' remarks as summit approaches', The Guardian, 28 November, 2019.

https://www.theguardian.com/world/2019/nov/28/macron-defends-brain-dead-nato -remarks-as-summit-approaches.

4 Launched at the Hague, the Netherlands, on 9 February 2019, the IMCCS seeks to address the growing demands from military professionals around the world for 
“...[It] provides global and regional assessments of the security risks of a changing climate, as well as opportunities for addressing them. It is the first report of its kind, and is intended to inform future climate and security policy analysis." 5

NATO itself has been slow to respond to the issues of climate change and security-climate security. Because it is primarily a military alliance depending on the will of its 30 member countries to cooperate, it has been difficult to move past institutional rhetoric. The difficulties of such coordination are evident in the attempts to develop a 'Green Defence Framework', which bears little resemblance to a framework and is more akin to a good practice exchange exercise. Yet, if progress has been slow institutionally, NATO allied navies have been tackling the effects of climate change on international security for quite some time. In fact, some might say that their inherent diplomatic nature-'soft power'-may well be ground for international cooperation on the matter; it might even serve to reinforce NATO's ties with partner nations and other allies.

\section{NATO and Climate Security: Energy Efficiency}

Understanding the relationship between NATO and climate security is as complex as understanding climate security itself. In its most basic definition, NATO is a military alliance of ' 30 independent member countries', 6 whose key commitment to each other is spelled out in Article 5 of the Washington Treaty (emphasis added):

"The Parties agree that an armed attack against one or more of them in Europe or North America shall be considered an attack against them all and consequently they agree that, if such an armed attack occurs, each of them, in exercise of the right of individual or collective self-defence recognised by Article 51 of the Charter of the United Nations, will as-

'sharing information and best practices on addressing the security and military dimensions of climate change'.

"About", IMCCS, accessed 15 January 2021. https:/imccs.org/about/.

5 Product of the Expert Group of the International Military Council on Climate and Security, "The World Climate and Security Report 2020", edited by Francesco Femia and Caitlin Werrell, (Center for Climate and Security, an institute of the Council on Strategic Risks, 2020), 3.

6 “NATO Member Countries", NATO, accessed 15 January 2021. https://www.nato.i nt/cps/en/natohq/nato_countries.htm. 
sist the Party or Parties so attacked by taking forthwith, individually and in concert with the other Parties, such action as it deems necessary, including the use of armed force, to restore and maintain the security of the North Atlantic area."

In other words, the focus of the alliance is on the North Atlantic area, and the key trigger for individual or collective self-defence is an armed attack.

The notion that climate change presents an international security risk has gained significant traction over the past decade. However, most of the research in the 2000s and early 2010s focused essentially on the effects of climate change on the already precarious security situation of fragile states. Actions to be taken to mitigate such effects were therefore essentially rooted in the realm of Humanitarian Assistance/Disaster Relief (HA/DR) and, to some extent, development.

The publication of the report 'A New Climate for Peace'7 in 2015 significantly contributed to refocusing the debate on a more international scale. As the introduction to the report itself notes,

"Unlike many of the previous reports on climate change and security, this report takes a broader look at fragility, viewing climate change impacts as pressures on states and societies that produce a wide range of fragility risks $[\ldots]$ It reaches beyond the traditional focus on the weakest and most conflict-ridden states by calling attention to the risks posed by climate change for the stability and resilience of more developed countries." 8

Given that, for the best part of the 2000s, climate security was seen to primarily affect developing nations and that it does not constitute an armed attack, it is indeed difficult to see how it could be relevant to NATO.

7 The report was commissioned by G7 foreign ministries and prepared by a consortium including Adelphi, International Alert, Woodrow Wilson International Centre for Scholars and European Union Institute for Security Studies.

8 Lukas Rüttinger, Dan Smith, Gerald Stang, Dennis Tänzler and Janani Vivekananda, "A New Climate for Peace: Taking Action on Climate and Fragility Risks", Report commissioned by G7 members, edited by Meaghan Parker (adelphi, International Alert, Woodrow Wilson International Centre for Scholars, European Union Institute for Security Studies, 2015). 


\section{NATO Green Defence}

In fact, as an alliance, NATO came to address the relationship between climate change and security by way of energy security. The first steps were taken in 1969 with the establishment of the Committee on the Challenges of Modern Society. The main focus of the Committee revolved around seeking to reduce the harmful impact of military operations on the environment and adapting military assets to the increasingly hostile environments they were called upon to operate in. ${ }^{9}$

There is little evidence, however, that member countries developed significant initiatives in that direction during the second half of the $20^{\text {th }}$ century. The real push for the alliance to start looking into climate change came with the 2008 financial crisis. ${ }^{10}$ Under significant pressure to limit public spending, countries around the world introduced austerity measures that included important defence budget cuts. ${ }^{11}$ However, because during that time a number of NATO members were still involved in the ongoing conflicts in Afghanistan and Iraq, they had to seek new ways to cut costs. Energy consumption emerged as one of the key solutions.

NATO recognises that energy "is fundamental to the execution and sustainment of military missions", according to the SMART Energy Team (SENT) comprehensive report (2015): "Operational energy efficiency is a key component of ensuring operational resiliency and reducing the financial and logistical challenges of sustaining NATO deployments." 12 This came to be known as 'smart energy', and it was only in the Chicago Summit of May 2012 that allied heads of state and government agreed to work

9 Niklas Bremberg, "European Regional Organisations and Climate-Related Security Risks: EU, OSCE and NATO”, SIPRI Insights on Peace and Security, No.1 (2018),11.

10 Kristian Knus Larsen, "Unfolding Green Defence: Linking green technologies and strategies to current security challenges in NATO and the NATO member states”, (Center for Military Studies, University of Copenhagen, 2015), 4.

11 Data on NATO members' defence spending as part of their GDP between 1990 and 2013 shows that all countries-except Albania—significantly reduced their defence spending as part of their GDP in 2009:

Public Diplomacy Division, 'Financial and Economic Data Relating to NATO Defence', NATO, 24 February 2014. https:/www.nato.int/nato_static_fl2014/assets/p df/pdf_topics/20140224_140224-PR2014-028-Defence-exp.pdf.

12 SENT, "Smart Energy Team (SENT) Comprehensive Report-On Nation's needs for energy in military activities, focusing on a comparison of the effectiveness of national approaches to reduce energy consumption", NATO Science for Peace and Security Programme (2015), 1. 
towards significantly improving the energy efficiency of their forces. The pledge led to the creation of SENT in October 2012 and was reiterated in the Wales Summit Declaration in 2014, giving birth to the 'Green Defence Framework'. ${ }^{13}$

The Green Defence Framework does not, per se, establish any specific targets or make any specific demands for efficient or environmentally sustainable activities. Rather, it highlights a number of existing initiatives that could contribute to its three pillars: (1) reinforcing the efforts of NATO bodies, (2) facilitating allies' efforts and (3) improving NATO's green profile. ${ }^{14}$ In other words, it encourages good practice exchange amongst NATO members aimed at increasing energy autonomy and reducing the impact of military operations on the environment.

\section{The Limits of the Green Defence Concept}

One of the key issues of the Green Defence Framework is that it offers limited information on how the impact of each smart energy initiative is to be measured. NATO is a military alliance heavily dependent upon member nations' common understanding of the key concepts that drive it. The same applies to smart energy. Without a clear definition of the criteria against which national defence smart energy initiatives are to be evaluated, it is difficult to establish a solid basis for a true energy-efficient, resilient and sustainable alliance.

Larsen offers a great example of such challenges by comparing the initiatives taken by the US Navy (USN) and the Italian Navy. In 2009, then US Secretary of the Navy Ray Mabus announced that the Department of the Navy would reduce its energy consumption. ${ }^{15}$ Part of the plan was the development and deployment of the 'Great Green Fleet'. ${ }^{16}$ The concept of the Great Green Fleet relied on the development of alternative sources of energy and looked closely at the use of biofuels. In 2014, noticing that the

13 ibid.

14 Larsen, Unfolding, 8.

15 This was based on five specific energy goals: change how the US Navy and Marine Corps awards contracts; develop and deploy the 'Great Green Fleet'; reduce petroleum use in the commercial fleet by $50 \%$ by 2015 ; produce at least half of the shore-based energy requirements from alternative power sources by 2020; and, by $2020,50 \%$ of the Navy's fuel consumption in ships, aircraft, tanks, vehicles and shore installations were to be from alternative power sources.

16 Larsen, Unfolding, 15. 
USN was making some headway in this direction, ${ }^{17}$ the Italian Navy followed suit and took its first steps towards the establishment of the Flotta Verde (Green Fleet) with a successful five-hour sea trial demonstration of the use of biofuels on ITS Foscari. Initiated in close cooperation with the USN, the Italian project benefited from the experience and lessons learnt from its American ally.

Despite their successful demonstration of the use of biofuels on board navy ships without significantly altering the architecture or systems of the ships, the two projects were heavily criticised. One of the key issues was, in fact, that though biofuels were less harmful to the environment, they did not, however, contribute to energy resilience. The fluctuating prices of crops-likely driven by the increasing demands for these biofuels-had a hand in making the navies highly vulnerable to price changes, which in turn negatively affected their budgets. Larsen concludes: "A precise and narrow description of challenges, tasks, technological solutions, and the links between them will reduce the risk of developing ineffective technologies $[\ldots]$... ${ }^{18}$

The SENT comprehensive report reveals another key issue concerning the Green Defence Framework's effectiveness. In preparation for its 2015 report, SENT submitted a questionnaire to NATO members and partner nations to understand "the needs for advocating energy efficiency related to their strategies, projects and definitions". ${ }^{19}$ Only 13 nations replied to the questionnaire. ${ }^{20}$ Yet already a number of key issues emerged: ${ }^{21}$

- Only a few nations have developed Defence Energy Strategies. This also means that only a few nations have a clear definition of what 'military energy efficiency' and/or 'operational energy' actually entail.

17 In 2012, during the Rim of the Pacific exercise (RIMPAC), the USN successfully demonstrated the performance of replacement biofuel blends in five of its vessels: the carrier USS Nimitz, the destroyers USS Chafee and USS Chung Hoon, the missile cruiser USS Princeton and the fleet replenishment oiler USNS Henry J. Kaiser (Larsen, Unfolding).

18 Larsen, Unfolding, 18.

19 SENT, Smart Energy, 11.

2011 NATO countries and two partner nations-according to SENT this essentially reflected the difficulties in acquiring an overview of national efforts on the issue, especially as it was difficult for many countries to provide a single point of contact on smart energy.

21 SENT, Smart Energy, 34-59. 
- Most national efforts are focused on increasing energy efficiency for domestic defence infrastructure; very few are looking into energy efficiency during operations.

- Most national efforts are focused on land forces, while very few countries have projects related to navies. Numbers are even lower for marines.

\section{Strategic Implications}

At the strategic level, it would seem that NATO allied countries, and their navies in particular, are still attempting to find their footing in a rapidly shifting world affected by climate change. The Green Defence Framework is a good starting point for reflection. Yet, to date it has failed to produce a real framework for extended cooperation and best practice exchange on how to ensure that deployed forces can be energy resilient and, at the same time, reduce their harmful effects on the environment.

A cursory glance at the naval industry across NATO members shows that a few steps are being taken, in particular in relation to energy consumption for increased asset autonomy. This is certainly critical for mission survivability but does little to reduce dependency on certain resources such as oil, which are vulnerable to price hikes and volatile geopolitical relations. Research is under way to find alternative fuels that could decrease such dependency and limit budget costs, ${ }^{22}$ as well as technologies that can reduce the harmful effect of naval assets on ocean ecosystems. ${ }^{23}$ But the road ahead remains long.

\section{NATO and Climate Security: A View from the Top}

NATO's institutional understanding of climate security as a risk that could trigger an Article 5 response has been slow to develop. The concept of climate change was only institutionalised in the 2010 Strategic Concept for the Defence and Security. ${ }^{24}$ The document recognises that

22 Larsen, Unfolding, 21-30.

23 For instance, although it has drawn much less attention than some bigger energy efficient projects, some navies have taken steps to improve their ballast water treatment to avoid them having a harmful impact on local marine ecosystems.

24 Rickard Söder, "NATO in a climate of change", SIPRI, 14 February 2020. https://www.sipri.org/commentary/blog/2020/nato-climate-change. 
"Key environmental and resource constraints, including health risks, climate change, water scarcity and increasing energy needs will further shape the future security environment in areas of concern to NATO and have the potential to significantly affect NATO planning and operations." 25

Yet it took nearly another decade for NATO to start defining its own role in addressing climate security challenges. In 2016, NATO's Secretary General Jens Stoltenberg was still reportedly commenting that "NATO is not a first responder to climate change", and consequently "the most important things that can be done with climate change are more related to energy, to ministers of the environment, to other areas than defence". ${ }^{26}$ This is in stark contrast to Stoltenberg's more recent (virtual) address at the University of Copenhagen in September $2020,{ }^{27}$ where he stated that NATO should be concerned with climate change because it makes the world more dangerous, it makes it harder for military forces to keep people safe, and because NATO has a responsibility to combat climate change. ${ }^{28}$

Nevertheless, if NATO as an organisation has found it quite difficult to take concrete steps in addressing climate security, allied navies, on the other hand, have been taking active steps at capability and strategic levels. And while it is not within the realm of this chapter to analyse the actions of all 30 member countries, the following subsections provide a few examples of action taken by NATO navies at the individual and regional levels to tackle climate security.

25 NATO, 'Strategic Concept for the Defence and Security of the Members of the North Atlantic Treaty Organisation', NATO (2010), 13.

26 'Politico Brussels playbook cocktails with Jens Stoltenberg', POLITICO, 6 June 2016, cited in Niklas Bremberg, "European Regional Organisations and ClimateRelated Security Risks: EU, OSCE and NATO”, SIPRI Insights on Peace and Security, No. 2018/1, 11.

27 Jens Stoltenberg, "NATO and the security implications of climate change-Virtual speech by NATO Secretary General Jens Stoltenberg”, NATO, 28 September 2020.

https:/www.nato.int/cps/fr/natohq/opinions_178355.htm?selectedLocale=fr.

28 This reflects the significant rhetorical steps also taken during the NATO Engages Summit in London in December 2019. 
The Arctic: Competition in the Air

The Arctic has been warming up at an alarming pace in the past decade. The sea-ice extent ${ }^{29}$ continues to reach new record lows, December 2020 being the third lowest on satellite record. ${ }^{30}$ This has opened up new ways of accessing its rich mineral seabed. It has also resulted in the two key regional passages, the Northern Sea Route ${ }^{31}$ (NSR) and the North-West Passage, ${ }^{32}$ becoming navigable for longer periods of the year (Figure 1).

\section{Figure 1 -Arctic Shipping Routes}
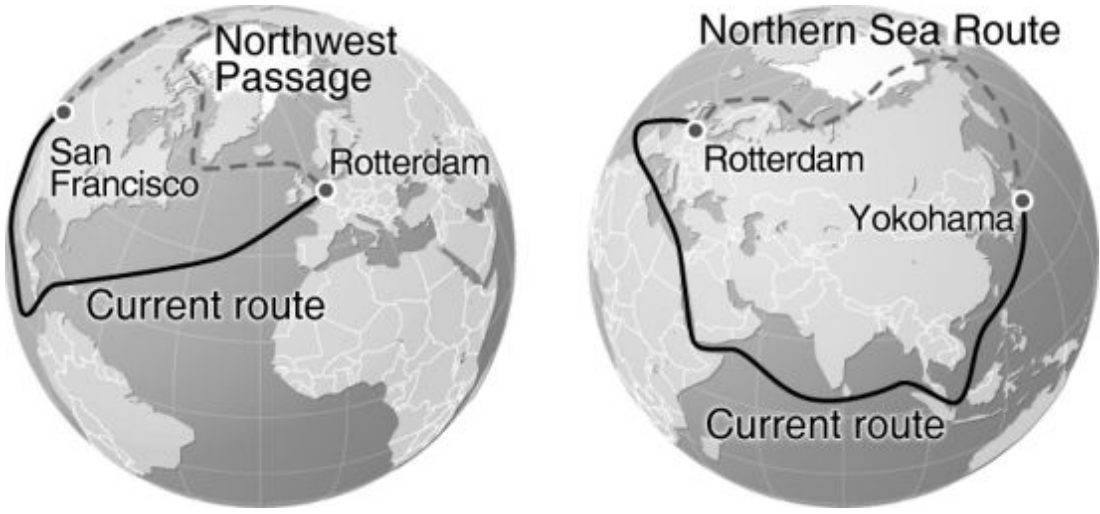

Source: European Space Agency (ESA)

While these routes, for the time being, are far from being able to accommodate the maritime trade that would significantly save time and costs for a number of trade actors in the region, they have already become a main point of contention: ${ }^{33}$

- Russia and Canada consider the NSR and the North-West Passage to be national waters and would seek to charge revenue for maritime passage

29 Sea ice extent is a measurement of the area of ocean where there is at least some sea ice. Usually, scientists define a threshold of minimum concentration to mark the ice edge; the most common cut-off is at 15 per cent (National Snow and Ice Data Centre-NSIDC).

30 NSIDC, “Arctic Sea Ice News and Analysis”, accessed 18 January 2021. http://nsid c.org/arcticseaicenews/.

31 Runs along the coast of the Eurasian.

32 Links the Atlantic to the Pacific Ocean through Canadian islets.

33 IMCCS, "The World Climate and Security Report 2020", 29. 
once the routes become navigable for longer periods in the year. To the US and other regional players, these claims are unacceptable.

- The NSR has the potential to reduce Chinese maritime trade to Europe by 15 days in comparison to the current route via the Strait of Malacca and the Suez Canal. China's 2018 first Arctic Policy highlights very clearly the country's ambitions for a Polar Silk Road in the region.

- Multiple territorial claims have been filed with the Commission on Arctic Shelves of the United Nations Convention of the Law of the Sea (UNCLOS), with Canada, Denmark and Russia having the most extensive claims.

UNCLOS verdicts on the continental shelf extensions claims are not out yet, and the price of developing the appropriate technologies to extract natural resources from the Arctic is still too high compared to the revenue that can be derived from them. Conflict, therefore, is far from imminent in the Arctic region, yet a number of regional allied navies have been renewing some key assets in their fleets.

This is notably the case for Norway, who has been looking at increased Russian activity around Svalbard with particular attention: by 2011 the Royal Norwegian Navy had already replaced five small frigates with five larger frigates equipped to fight anti-air, anti-submarine and anti-surface warfare; ${ }^{34}$ it will also be replacing its submarines soon. Less concerned about security threats than its Scandinavian neighbour, ${ }^{35}$ the Royal Danish Navy has acquired ice-strengthened Offshore Patrol Vessels ${ }^{36}$ (OPV) as well as new helicopters ${ }^{37}$ for its frigates in order to monitor potential activity in the area. In North America, in a bid to increase its presence in the Arctic, the Royal Canadian Navy signed a contract in 2015 for five 'Harry DeWolf class Arctic Ocean Patrol Vessels (AOPV).

34 Alix Valenti, 'Fire and Ice-Naval Build-Up in the Arctic', Naval Forces, No. IV (2018), 51.

35 Talking to the author in 2018, Rear Admiral Nils Wang, then Director of Naval Team Denmark and Commandant at the Royal Danish Defence College said: "The Arctic region has been prioritised, with a government focused on Arctic issues and challenges; however, this does not stem from the Danish perception that there is a threat against its territories.", ibid.

36 Two 'Knud Rasmussen' class to replace the ageing 'Agdlek' class, which are capable of breaking $40 \mathrm{~cm}$ sea ice and have a range of $5600 \mathrm{~km}$, ibid.

37 Nine Seahawk helicopters from the USN-these helicopters will be able to carry out anti-surface and anti-submarine warfare, ibid. 


\section{Indo-Pacific: Between HA/DR and Strategic Interests}

The Indo-Pacific region may appear geographically unrelated to NATO, yet it is home to five of the 12 French overseas territories, ${ }^{38}$ two United Kingdom overseas territories ${ }^{39}$ and a large number of US Pacific territories. ${ }^{40}$ These overseas territories allow these NATO members to lay sovereign claims to Pacific and Indian Ocean waters; they also represent a significant responsibility in terms of protection.

The Indo-Pacific region is the world's most disaster-prone region. ${ }^{41} \mathrm{~A}$ large number of Pacific ${ }^{42}$ and Indian Ocean islands are at risk of being submerged in the coming years if the sea level continues to rise as it has over the past decade. ${ }^{43}$ They are also highly vulnerable to extreme weather events. ${ }^{44}$ Finally, fish stocks are being driven away from the coasts ${ }^{45}$ as a result of coral bleaching. These trends have three significant impacts on climate security in the Indo-Pacific region:

- Depleted regional fish stocks are driving up illegal, unreported, unregulated (IUU) fishing, the most recent figures estimating the value of tuna

38 Mayotte and La Réunion in the Indian Ocean; Wallis et Futuna, French Polynesia and New Caledonia in the Pacific Ocean.

39 British Indian Ocean Territory in the Indian Ocean; Pitcairn Islands in the Pacific Ocean.

40 Midway Island, Hawaiian Islands, Northern Marian Islands, Guam, Wake Island, Howland and Baker Island, American Samoa, Jarvis Island, Johnston Island, Palmyra Atoll and Kingman Reef.

41 IMCCS, "The World Climate and Security Report 2020", 42.

42 Kiribati, for instance, is barely two metres above sea level at its highest point (IMCCS, 2020, 46).

43 Since 1993, the sea level has been rising at an average of $3.29 \mathrm{~mm}$ per year, peaking in 2020.

WMO, "State of the Global Climate 2020 - Unpacking the Indicators", 14 January 2021.

https://public.wmo.int/en/our-mandate/climate/wmo-statement-state-of-global-cli mate.

44 In 2019 five cyclones built-up over the Indian Ocean.

EUMETSAT, "Active Indian Ocean tropical cyclone season”, accessed 19 January 2021.

https://www.eumetsat.int/active-indian-ocean-tropical-cyclone-season.

45 Coral reefs only occupy $0.1 \%$ of the world's oceans but they support $25 \%$ of all marine species on the planet. Coral bleaching is therefore also likely to further deplete fish stocks as marine ecosystems are disrupted. WWF, "What are the main threats to coral reefs?", accessed 19 January 2021. https:/wwf.panda.org/discover/ our_focus/oceans_practice/coasts/coral_reefs/. 
and tuna-like products lost to illegal trans-shipments at \$142 million each year. ${ }^{46}$

- Populations living in areas prone to extreme weather events, such as typhoons, cyclones and flooding, are being displaced to other areas or countries. This potentially creates tensions over resources, which could become sources of conflict.

- Some populations may not wish to move away from their homes or hometowns, exposing themselves to recurrent climate-related disasters.

As a consequence, all three countries have blue water navies that include capabilities designed to defend their interests and deliver HA/DR in regions as far from home as the Indian Ocean and the Pacific.

If we look more specifically at France, the French EEZ in the Indian Ocean represents $25 \%$ of the country's total EEZ (see Figure 2). The French Navy therefore plays a significant role in protecting national interests in the region. It has three naval bases in the region-in Djibouti, La Reunion and Abu Dhabi ${ }^{47}$-from which ships are regularly deployed to protect Sea Lines Of Communication (SLOC). SLOCs may appear disconnected from the issue of climate security; in reality, as noted by the French Naval Centre for Strategic Studies (CESM) in its 2016 report on 'Naval ambition in the $21^{\text {st }}$ century':

"The sea determines the economic future of our country, of Europe and of mankind: three quarters of the world population live within $500 \mathrm{~km}$ of the coast, potentially large quantities of ocean resources are mostly untapped while those of the earth are exhausted. Moreover, $90 \%$ of our globalised economy relies on maritime transport security and $95 \%$ of our intercontinental digital communications passes through submarine cables." 48

46 MRAG Asia Pacific in S. Widjaja, T. Long, H. Wirajuda et al., "Illegal, Unreported and Unregulated Fishing and Associated Drivers”, (Washington, DC: World Resources Institute 2019). Available online at www.oceanpanel.org/iuu-fishing-and-associated-drivers.

47 Bastien Alex, Alice Baillat and François Gemenne, 'Rapport d'Etude n¹0: Changements climatiques et enjeux de defense dans l'ocean Indien occidental', (IRIS/IFRI 2019), 32.

48 CESM, 'Ambition Navale au XXI' siècle', (CESM, 2016), Hors Série, 15. 
Figure 2- France's Strategic Interests in the Indian Ocean

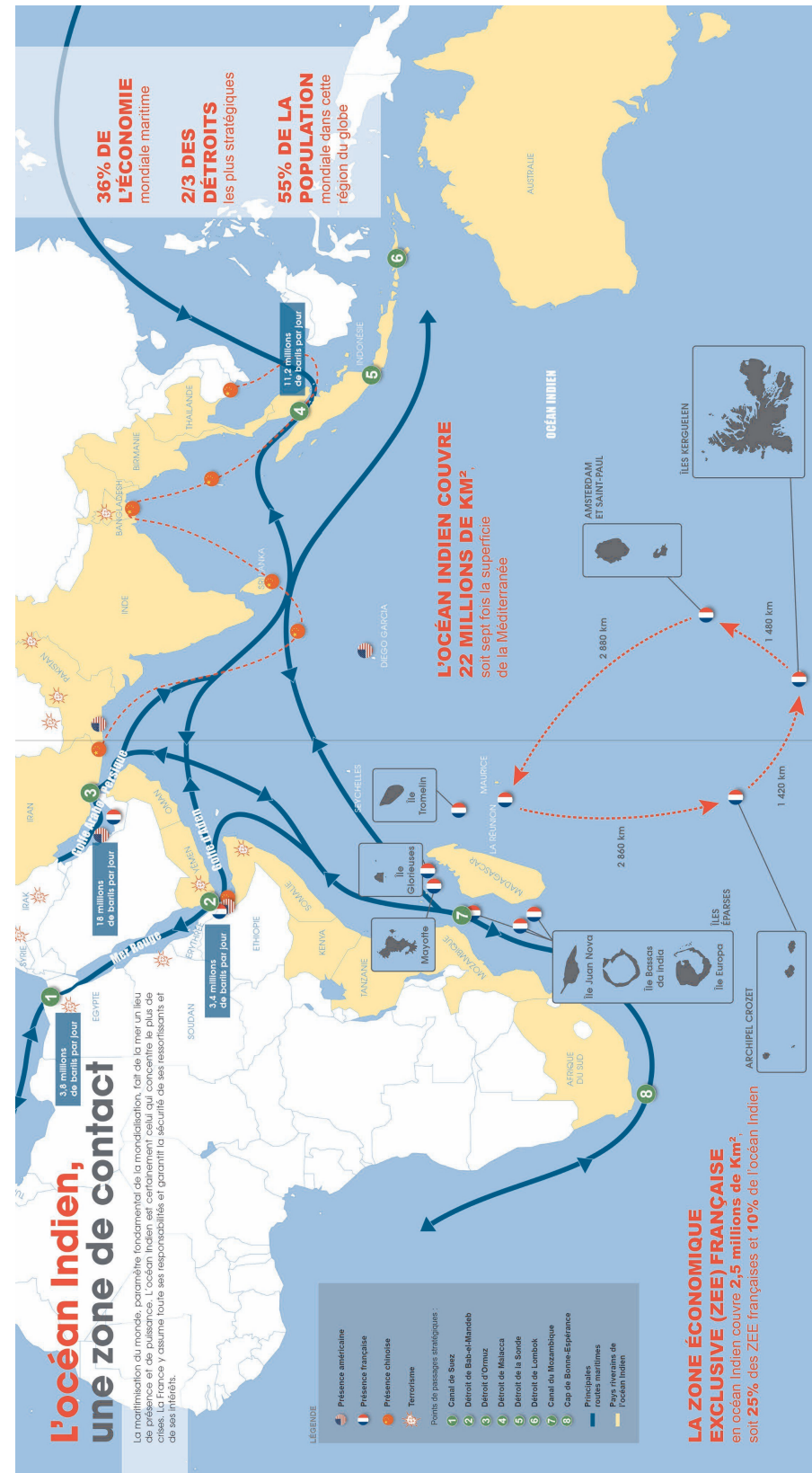

Source: Marine Nationale ${ }^{49}$ 
In the Indian Ocean, the French Navy is also seeking to provide support to authorities in Mayotte in their fight against illegal migration from the Comoros. Finally, at a more general level, the French Navy is seeking to establish good cooperation with regional countries and powers around the concept of 'Blue Economy'. ${ }^{50}$ 'Blue Economy' covers all economic activities related to oceans, seas and coasts ${ }^{51}$-all activities related to climate security. ${ }^{52}$

On the Pacific front, regional waters are home to 40\% of France's $\mathrm{EEZ} ;{ }^{53}$ it represents an invaluable strategic asset by way of its position and the natural resources lying in its seabed. Aside from patrolling the waters to protect national sovereignty, the French Navy also seeks to develop missions to fight against illegal trafficking and other activities in the region. ${ }^{54}$ As Chinese fishing activity continues to grow in the region ${ }^{55}$ (Figure 3), France is growing increasingly attentive to what is happening in its regional territorial waters. The French Navy also stands ready to cooperate with regional actors in their efforts to provide HA/DR where needed.

49 https://witter.com/MarineNationale/status/966305311668699136/photo/1.

50 ibid., 37.

51 European Commission, 'What is the Blue Economy', accessed 19 January 2021. https:/ec.europa.eu/maritimeaffairs/sites/maritimeaffairs/files/docs/publications/ what-is-the-blue-economy_en_1.pdf.

52 Aquaculture, fishing, coastal tourism, maritime transport, coastal and environmental protection, to name a few, ibid.

53 The total French EEZ encompasses $11 \mathrm{~km}^{2}$, and the French overseas territories in the Pacific represent a total of $4.5 \mathrm{~km}^{2}$ of EEZ (approximately $40 \%$ ).

Vie Publique, "Mers et oceans: les espaces maritimes en six questions", accessed 19 January 2021.

https://www.vie-publique.fr/questions-reponses/274664-mers-et-oceans-les-espacesmaritimes-en-six-questions.

54 CESM, 'Ambition Navale au XXI' siècle', 39.

55 FAO, "Fishery Statistical Collections - Global Capture Production", queried 19 January 2021.

www.fao.org/figis/servlet/SQServlet?file=/usr/local/tomcat/8.5.16/figis/webapps/fig is/temp/hqp_6048625640213625301.xml\&outtype=html. 
Figure 3 -Chinese fishing statistics in the South-West and South-East Pacific Ocean

\section{Capture: Quantity (t)}

\begin{tabular}{|c|c|c|c|c|c|c|c|c|c|}
\hline \multicolumn{2}{|c|}{ Display Land Area: } & $\hat{v}$ & ok & & \multicolumn{5}{|c|}{ EXPORT } \\
\hline Land Area & Ocean Area & 2011 & 2012 & 2013 & 2014 & 2015 & 2016 & 2017 & 2018 \\
\hline \multirow[t]{2}{*}{ China } & Pacific, Southeast & 283619 & 274921 & 274353 & 359552 & 357742 & 251566 & 332651 & 379664 \\
\hline & Pacific, Southwest & 3002 & 3518 & 5044 & 5481 & 6748 & 6108 & 7025 & 5347 \\
\hline \multicolumn{2}{|l|}{ Total China } & 286621 & 278439 & 279397 & 365033 & 364490 & 257674 & 339676 & 385011 \\
\hline \multicolumn{2}{|l|}{ Grand total } & 286621 & 278439 & 279397 & 365033 & 364490 & 257674 & 339676 & 385011 \\
\hline
\end{tabular}

Source: FAO_-Fisheries and Aquaculture Information and Statistics Branch: Interrogated on 25/01/2021.

As noted earlier, the French Navy is not the only regional actor with an increasing presence in the Indo-Pacific region. By way of its extensive EEZ in the Pacific Ocean, the USN also regularly patrols those waters to protect both its national interests and freedom of navigation. A report published by the Centre for Naval Analysis (CNA) in 2007 already noted that, "climate change threats also create opportunities for constructive engagement such as stability operations and capacity building". ${ }^{56}$ In the region, the USN cooperates extensively with its partners, especially Australia, on security issues; although the majority revolve around warfare, exercises like the Rim of the Pacific (RIMPAC) have also increasingly included training focused on the Blue Economy as well.

The presence of these two NATO countries in the far waters of the IndoPacific presents the alliance with significant potential. Leveraging cooperation programmes and exercises between France, the USN and their regional partners, NATO could strengthen old alliances and build new ones around the concept of climate security.

\section{NATO's Window of Opportunity in a Changing Climate}

NATO has been very slow in institutionalising the concept of climate change. Today still, the alliance has taken no concrete steps to address the impact of climate change on international security. Undoubtedly, part of the issue lies in rhetoric. 'Climate change' is a controversial concept, a reef

56 CNA, 'National Security and the Threat of Climate Change', (CNA 2007), 39. 
that sees many conversations stranded around the debate of man-made versus not man-made. NATO has been no exception to this pitfall.

Yet, the introduction of the concept of 'climate security' in the mid-2010s may well have played a significant role in reshaping institutional mindsets in the last few years. It shifted the debate away from the root causes of climate change to focusing, instead, on the effects of climate-related disasters on international security. The relationship between the devastating effects of warming oceans-on coral reefs, rising sea levels and weather systems - and human insecurity is much easier to agree upon.

Allied navies could be key enablers in supporting NATO's transition towards a more defined agenda on tackling climate security. Over the past three decades, allied blue water navies have been "called to respond to a wide range of natural or man-made threats that have little or nothing to do with questions of war or peace". ${ }^{57}$ Progressively, they have played a significant role in protecting populations and national interests well beyond the North Atlantic region. For instance, as discussed in this chapter, through close cooperation with regional partners in the Indian and Pacific Oceans, the French and US navies are contributing to a wide range of missions that aim at protecting national interests against the effects of climate insecurity - protection of SLOCs crucial to maritime trade, action against IUU fishing and illegal migration, to name but a few.

These non-military responsibilities "break the traditional mould regarding what most people think are navies' primary duties". ${ }^{58}$ Through their actions on climate security, they have become an essential instrument of soft power. As noted by Bastien, A., Baillat, A. and Gemenne, F. (2019), cooperation around the notion of a Blue Economy could create windows of opportunity for regional dialogue with unexpected regional actors. ${ }^{59}$ In the Indian Ocean, for instance, China has become a logical player and a potential partner for HA/DR; "it would be a good way to engage in a constructive dialogue with China in relation to its role in the Indian Ocean". ${ }^{60}$ Similarly, a more clearly defined 'Green Defence Framework' could sup-

57 Bruce E. Elleman and S.C.M. Paine, 'Introduction: Navies Are Not Just for Fighting', in Navies and Soft Power: Historical Case Studies of Naval Power and the Nonuse of Military Force, ed. Bruce E. Elleman and S.C.M. Paine, (Naval War College Press 2015), 1.

58 Ibid, p.2.

59 Alex, Baillat and Gemenne, 'Rapport d'Etude n¹0, 32.

60 Ibid. 
port navies in using soft power to form research partnerships seeking to reduce the harmful effects of naval assets on marine life. ${ }^{61}$

A soft power approach built around the notion of Blue Economy may not be easily implemented. In regions where climate security meets the resurgence of great power competition, building naval cooperation towards common goals may prove challenging. ${ }^{62}$ For instance, navy modernisation programmes that have been taking place in the Arctic amidst contentious sovereignty claims, Russia's more assertive behaviour and China's increased interest in the region presage everything but a sense of peaceful trust. Similarly, other regions that could not be discussed in this chapter-such as the Mediterranean ${ }^{63}$ - may also suffer from tensions related to resource competition between NATO members. But, as Elleman, B. and Paine, S.C.M. (2015) note ${ }^{64}$ :

"Many navies and coastguards cooperate with those of other countries to conduct these missions because all nations share a common interest in safe transit and healthy fisheries."

If NATO plays its cards well and defines more clear strategic goals within the notion of climate security, it may have more solid ground on which to build cooperation with nations around the world. And what is currently a relentless hazard may, in the end, have a silver lining.

61 Darlene R. Ketten, 'Naval Sonars, Strandings, and Responsible Stewardship of the Seas', in Navies and Soft Power: Historical Case Studies of Naval Power and the Nonuse of Military Force, edited by Bruce E. Elleman and S.C.M. Paine, (Naval War College Press 2015), 127.

62 The IMCCS (2020, p.30) report highlights the difficult relations between countries with competing continental shelf claims and who sit at the same regional institutional table. Notably, this is the case with Russia and the Arctic Panel.

63 The Mediterranean region and the black sea are currently disrupted by regional conflicts, resources competition, illegal trafficking and illegal migration (CESM, 2016, 35).

64 Bruce E. Elleman and S.C.M. Paine,, 'Conclusion: Breaking the Mold', in Navies and Soft Power: Historical Case Studies of Naval Power and the Nonuse of Military Force, edited by Bruce E. Elleman and S.C.M. Paine, (Naval War College Press 2015), 181 


\section{Works cited}

“About”, IMCCC, accessed 15 January 2021, https:/imccs.org/about/.

“NATO Member Countries”, NATO, accessed 15 January 2021, https://www.nato.i nt/cps/en/natohq/nato_countries.htm.

Alex, Bastien, Baillat, Alice and Gemenne, François, 'Rapport d'Etude $\mathrm{n}^{\circ} 10$ : Changements climatiques et enjeux de defense dans l'ocean Indien occidental', IRIS/IFRI, 2019.

Bremberg, Niklas, "European Regional Organisations and Climate-Related Security Risks: EU, OSCE and NATO", SIPRI Insights on Peace and Security, No. 1 (2018).

CESM, ‘Ambition Navale au XXI ${ }^{\circ}$ siècle', CESM, Hors Série, 2016.

CNA, 'National Security and the Threat of Climate Change', CAN, 2007.

Crowley, Michael, 'Allies and Former US Officials Fear Trump Could Seek NATO Exit in a Second Term', The New York Times, 3 September, 2020, https://www.ny times.com/2020/09/03/us/politics/trump-nato-withdraw.html.

Elleman, Bruce E. and Paine, S.C.M., 'Conclusion: Breaking the Mold', in Navies and Soft Power: Historical Case Studies of Naval Power and the Nonuse of Military Force, edited by Bruce E. Elleman and S.C.M. Paine, Naval War College Press, 2015, 181-199.

Elleman, Bruce E. and Paine, S.C.M., 'Introduction: Navies Are Not Just for Fighting', in Navies and Soft Power: Historical Case Studies of Naval Power and the Nonuse of Military Force, edited by Bruce E. Elleman and S.C.M. Paine, Naval War College Press, 2015, 1-5.

EUMETSAT, “Active Indian Ocean tropical cyclone season”, accessed 19 January 2021, https:/www.eumetsat.int/active-indian-ocean-tropical-cyclone-season.

European Commission, 'What is the Blue Economy', accessed 19 January 2021, https:/ec.europa.eu/maritimeaffairs/sites/maritimeaffairs/files/docs/publications/ what-is-the-blue-economy_en_1.pdf.

FAO, "Fishery Statistical Collections - Global Capture Production", queried 19 January 2021, www.fao.org/figis/servlet/SQServlet?file=/usr/local/tomcat/8.5.16/f igis/webapps/figis/temp/hqp_6048625640213625301.xml\&outtype=html.

Ketten, Darlene R, 'Naval Sonars, Strandings, and Responsible Stewardship of the Seas', in Navies and Soft Power: Historical Case Studies of Naval Power and the Nonuse of Military Force, edited by Bruce E. Elleman and S.C.M. Paine, Naval War College Press, 2015, 127-143.

Larsen, Kristian Knus, "Unfolding Green Defence: Linking green technologies and strategies to current security challenges in NATO and the NATO member states”, Centre for Military Studies, University of Copenhagen, 2015.

Marine Nationale (Twitter), https://twitter.com/MarineNationale/status/966305311 668699136/photo/1. 
MRAG Asia Pacific in S. Widjaja, T. Long, H. Wirajuda et al., "Illegal, Unreported and Unregulated Fishing and Associated Drivers", Washington, DC: World Resources Institute (2019), available online at www.oceanpanel.org/iuu-fishing-and -associated-drivers.

NATO, 'Strategic Concept for the Defence and Security of the Members of the North Atlantic Treaty Organisation', NATO, 2010.

NSIDC, “Arctic Sea Ice News and Analysis”, accessed 18 January 2021, http://nsidc. org/arcticseaicenews/.

Product of the Expert Group of the International Military Council on Climate and Security, "The World Climate and Security Report 2020", edited by Francesco Femia and Caitlin Werrell, Center for Climate and Security, an institute of the Council on Strategic Risks, 2020.

Public Diplomacy Division, 'Financial and Economic Data Relating to NATO Defence', NATO 24 February 2014, https:/www.nato.int/nato_static_fl2014/assets/ pdf/pdf_topics/20140224_140224-PR2014-028-Defence-exp.p̄df.

Rüttinger, Lukas, Smith, Dan, Stang, Gerald, Tänzler, Dennis and Vivekananda, Janani, "A New Climate for Peace: Taking Action on Climate and Fragility Risks”, edited by Meaghan Parker, Adelphi, International Alert, Woodrow Wilson International Centre for Scholars, European Union Institute for Security Studies, 2015.

SENT, “Smart Energy Team (SENT) Comprehensive Report-On Nation's needs for energy in military activities, focusing on a comparison of the effectiveness of national approaches to reduce energy consumption", NATO Science for Peace and Security Programme, 2015.

Söder, Rickard, "NATO in a climate of change", SIPRI, 14 February 2020, https://ww w.sipri.org/commentary/blog/2020/nato-climate-change.

Stoltenberg, Jens, "NATO and the security implications of climate change - Virtual speech by NATO Secretary General Jens Stoltenberg”, NATO, 28 September 2020, https://www.nato.int/cps/fr/natohq/opinions_178355.htm?selectedLocale= fr.

The Economist, 'Emmanuel Macron warns Europe: NATO is becoming braindead', The Economist, 7 November, 2019, https:/www.economist.com/europe/20 19/11/07/emmanuel-macron-warns-europe-nato-is-becoming-brain-dead.

Valenti, Alix, 'Fire and Ice - Naval Build-Up in the Arctic', Naval Forces, No. IV (2018), 50-52.

Vie Publique, "Mers et oceans: les espaces maritimes en six questions", accessed 19 January 2021, https://www.vie-publique.fr/questions-reponses/274664-mers-et-oc eans-les-espaces-maritimes-en-six-questions.

Wintour, Patrick and McKernan, Bethan, 'Macron defends "brain-dead NATO" remarks as summit approaches', The Guardian, 28 November, 2019, https://www.t heguardian.com/world/2019/nov/28/macron-defends-brain-dead-nato-remarks-as -summit-approaches. 
WMO, "State of the Global Climate 2020 - Unpacking the Indicators", 14 January 2021, https://public.wmo.int/en/our-mandate/climate/wmo-statement-state-of-gl obal-climate.

WWF, "What are the main threats to coral reefs?", accessed 19 January 2021, https:/ /wwf.panda.org/discover/our_focus/oceans_practice/coasts/coral_reefs/. 